\title{
Congenital myasthenia gravis: clinical and HLA studies in two brothers
}

\author{
A. M. Whiteley, M. S. SCHWARTZ, J. A. SACHS, AND M. SWASH \\ From the Section of Neurological Sciences, The London Hospital; \\ and the Tissue Immunology Unit, The London Hospital Medical College, London
}

SYNOPSIS Two brothers with congenital myasthenia gravis are described. In both, ptosis and ophthalmoplegia responded poorly to oral anticholinesterase therapy and to thymectomy. The brothers had two different HLA haplotypes and neither had the HLA-A1-B8-DW3 haplotypes, which are commonly associated with myasthenia gravis in adult-onset cases.

Congenital myasthenia gravis - that is, myasthenia beginning in the first two years of life-accounts for about $1 \%$ of all cases of myasthenia gravis (McLean and McKone, 1973). About half the reported cases of congenital myasthenia gravis are familial (Bundey, 1972; McLean and McKone, 1973) and in most of these the disease occurred in siblings, although there have also been reports of affected first cousins (Teng and Osserman, 1956) and nephews (Warrier and Pillai, 1967). There is a male predominance. Congenital myasthenia must be distinguished from neonatal myasthenia, a transient disorder which occurs in babies born to myasthenic mothers, and from myasthenia beginning after the second year of life. The latter resembles the adult-onset disease in distribution of weakness, female predominance, response to treatment, and an association with circulating tissue autoantibodies (Bundey, 1972).

The HLA region of chromosome 6 consists of a number of gene loci responsible for antigens which can be detected on the surface of circulating lymphocytes. The HLA-A, HLA-B, and HLA-C antigens can be detected serologically, and the HLA-D group of antigens are detected by the mixed lymphocyte reaction. A number of reports indicate that there is a higher frequency of HLA-B8 (formerly HL-A8) antigen in patients with myasthenia gravis than in a control population (Behan et al., 1973; Fritze et al. 1974; Pirskanen, 1976), and Haakinen et al. (1975) have suggested that HLA-B8 and its associated HLA-DW3 determinant are particularly prevalent in young, female myasthenics. There is a less significant association between HLA-A3 and adult-onset

(Accepted 14 July 1976.) myasthenia in males (Fritze et al., 1974). HLA tests have only rarely been applied to patients with congenital myasthenia (Dick et al., 1974).

In this paper we shall describe the clinical features of two brothers with congenital myasthenia, and the results of HLA antigen tests in the two patients and in their family.

\section{CASE 1}

( $L H$ 551472) This 29 year old labourer complained of droopy eyelids, which interfered with driving. His upper lids had been droopy at least since the age of 6 months. This symptom had not changed greatly since childhood but it was usually more noticeable in the evening, in hot weather, and after exertion. More recently he had noticed weakness of his jaw and lips when chewing.

On examination there was marked bilateral ptosis with resting exotropia (Fig. 1). There was marked impairment of elevation, depression, and adduction of each eye, and abduction was also incomplete (Table 1). Cogan's eyelid twitch sign was present. The facial, bulbar, trunk, and limb musculature was well developed, without weakness or fatiguability.

\section{CASE 2}

( $L H$ 628522) The 19 year old brother of case 1 was similarly affected in infancy (Fig. 2). At that time his mother noted that his cry seemed weak, and ptosis was first observed before the age of 6 months. A photograph of the two brothers taken 16 years ago illustrates the ptosis at that time (Fig. 3). The ptosis varied during the day. Sometimes, in the evening, he 


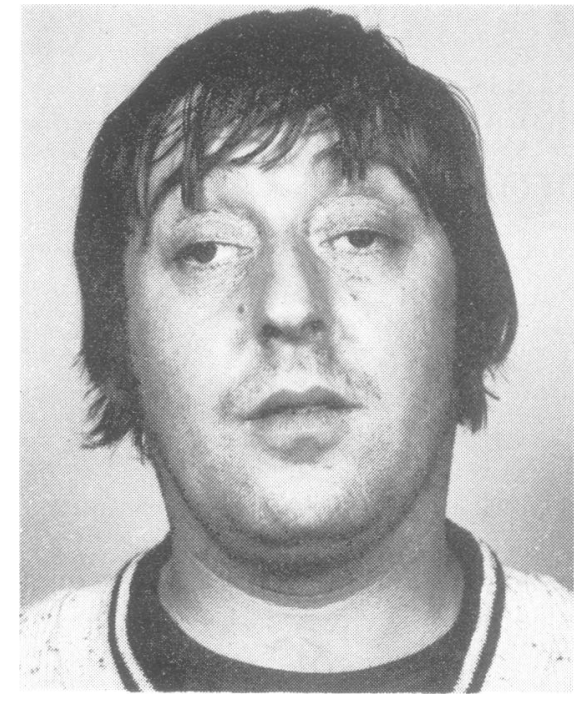

FIG. 1 Case 1 before thymectomy.

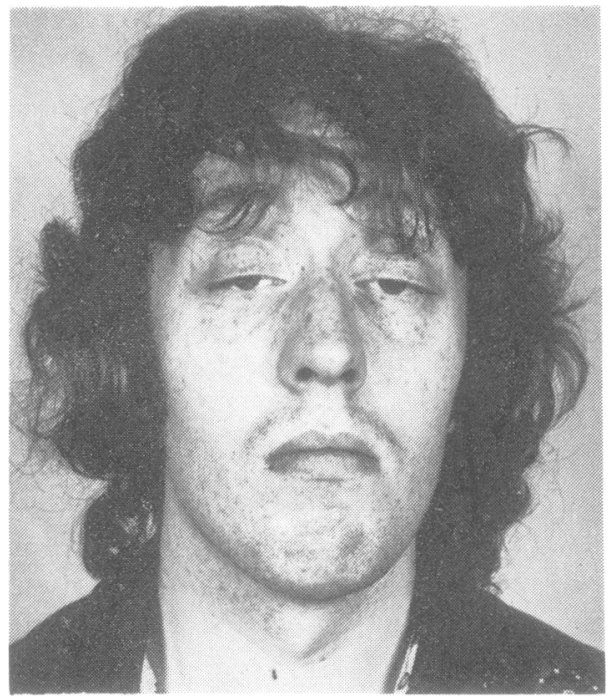

FIG. 2 Case 2 before thymectomy.

TABLE 1

CLINICAL DATA

\begin{tabular}{|c|c|c|c|c|c|c|c|}
\hline $\begin{array}{c}\text { Case } \\
\text { no. }\end{array}$ & $\begin{array}{l}\text { Age } \\
(y r)\end{array}$ & $\begin{array}{c}\text { Age at } \\
\text { onset } \\
\text { (months) }\end{array}$ & $\begin{array}{c}\text { Distribution of } \\
\text { weakness }\end{array}$ & $\begin{array}{l}\text { Edrophonium } \\
\text { response }\end{array}$ & $\begin{array}{l}\text { EMG and } \\
\text { repetitive } \\
\text { stimulation }\end{array}$ & $\begin{array}{l}\text { Muscle } \\
\text { biopsy }\end{array}$ & $\begin{array}{c}\text { Thymic } \\
\text { histology }\end{array}$ \\
\hline $\begin{array}{l}1 \\
2\end{array}$ & $\begin{array}{l}29 \\
19\end{array}$ & $\begin{array}{l}6 \\
6\end{array}$ & $\begin{array}{l}\text { Ocular } \\
\text { Ocular, facial, } \\
\text { shoulder }\end{array}$ & $\begin{array}{l}+ \\
+\end{array}$ & $\begin{array}{l}\text { Normal } \\
\text { Normal }\end{array}$ & $\begin{array}{l}\text { Normal } \\
\text { Normal }\end{array}$ & $\begin{array}{l}\text { Normal } \\
\text { Normal }\end{array}$ \\
\hline
\end{tabular}

had to hold his eyelids open when watching television, and in hot sunshine his eyelids often closed completely. He also complained of double vision when tired, and of inability to follow the ball at football matches. His arms tired easily.

On examination there was marked ptosis and ocular movements were very limited in all directions of gaze. Cogan's eyelid twitch sign was present. There was bilateral facial weakness. The trunk and limb muscles were poorly developed and there was mild weakness of shoulder abduction (Table 1).

\section{FAMILY HISTORY}

There was no clinical evidence of myasthenia gravis or of other neuromuscular disease, in the parents, the sister, the sister's children, or in the children of case 1. More distant relatives were not examined but were said to be normal.

\section{INVESTIGATIONS}

The complete blood count, ESR, thyroid function tests, tissue autoantibody screen including tests for antibodies to striated muscles, creatine phosphokinase, and chest radiograph were normal in both brothers.

After intravenous edrophonium hydrochloride $(10 \mathrm{mg})$ there was a marked transient improvement in the ptosis and ophthalmoplegia in both patients, and in case 2 the mild proximal upper limb weakness also improved. In both there was no decrement of the muscle action potential evoked by repetitive supramaximal stimulation of the ulnar nerve at the wrist at $2 \mathrm{~Hz}$ and $20 \mathrm{~Hz}$. Concentric needle EMG was normal in proximal and distal muscles in both brothers. Single fibre EMG (Ekstedt, 1964), performed in both patients (Table 2), revealed an increased neuromuscular jitter with impulse blocking 


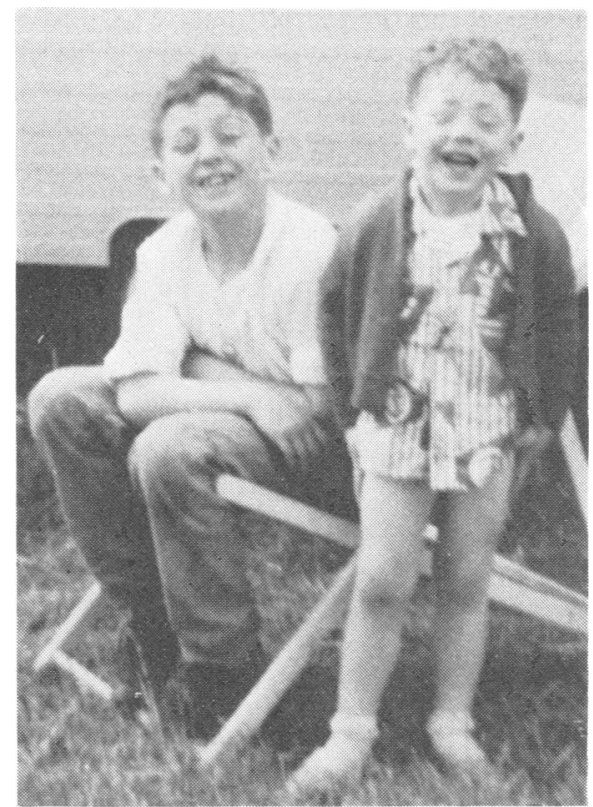

FIG. 3 The brothers when children aged 3 and 13 years.

(Stålberg et al., 1974) in the extensor digitorum communis muscle, although this muscle was clinically normal in both cases. A biopsy specimen taken from the deltoid muscle was examined using a standard series of enzyme histochemical methods (Dubowitz and Brooke, 1973) and in both cases the histology was normal.

\section{PROGRESS}

Treatment was begun with oral pyridostigmine in doses up to $600 \mathrm{mg}$ daily. Although both brothers felt generally stronger there was no objective improvement in ptosis or ophthalmoplegia during the following year. Since the ptosis and ophthalmoplegia produced considerable disability thymectomy was performed. In case 1 the thymus weighed $30 \mathrm{~g}$ : it contained many calcified Hassall's corpuscles and was half replaced by fat. There were no germinal centres in the cortex or medulla. In case 2 the thymus weighed $30 \mathrm{~g}$ : the cortex and medulla were normal and Hassall's corpuscles were present. Both thymus glands were thought to be normal (Dr A. H. E. Marshall).

Six months after thymectomy both brothers said that they felt stronger and there was a slight objective improvement in their ptosis. Both continued their pyridostigmine and both noticed increased ptosis when this was withdrawn for a few days. Single fibre EMG, repeated at this time, showed improvement in both patients: the neuromuscular jitter was abnormal in fewer potential pairs, and impulse blocking occurred less frequently than in the earlier examination (Table 2).

\section{HLA STUDIES}

A slightly modified National Institute of Health technique (Festenstein et al., 1972) was used to test for the serologically defined HLA-A, HLA-B, and HLA-C antigens. HLA-D typing was performed by using the cells from individuals homozygous for the various D locus antigens as the 'typing cells' and the test individuals and unrelated controls as the 'responder cell' (Bradley et al., 1972; Joint Report, 1975). One patient, his sister, and their mother were typed against several 'typing cells', which included six HLA-DW3 typing cells, one of which had been used in the Sixth Histocompatibility Workshop (Robinette et al., 1975). The normal response of the family members to the DW3 typing cells indicated that the family did not possess this antigen, although, as the HLA-DW specificity of the HLA-A3-B7 haplotypes was not tested, complete absence of the HLA-DW3 antigen remains uncertain. The HLA

TABLE 2

SINGLE FIBRE ELECTROMYOGRAPHY

\begin{tabular}{|c|c|c|c|c|}
\hline \multirow[b]{2}{*}{$\begin{array}{l}\text { Case } \\
\text { (no.) }\end{array}$} & & \multicolumn{3}{|c|}{ Single fibre EMG (20 potential pairs) } \\
\hline & & Normal & $\begin{array}{c}\text { Increased } \\
\text { jitter }\end{array}$ & $\begin{array}{c}\text { Increased jitter } \\
\text { and } \\
\text { impulse blocking }\end{array}$ \\
\hline 1 & $\begin{array}{l}\text { Preoperation } \\
\text { Postoperation }\end{array}$ & $\begin{array}{r}6 \\
13\end{array}$ & $\begin{array}{l}8 \\
5\end{array}$ & $\begin{array}{l}6 \\
2\end{array}$ \\
\hline 2 & $\begin{array}{l}\text { Preoperation } \\
\text { Postoperation }\end{array}$ & $\begin{array}{r}6 \\
14\end{array}$ & $\begin{array}{l}9 \\
5\end{array}$ & $\begin{array}{l}5 \\
1\end{array}$ \\
\hline
\end{tabular}

Normal neuromuscular jitter: mean consecutive deviation $<50 \mu \mathrm{s}$ (Stålberg et al., 1974). 
genotype of the family is given in Table 3. The two brothers had completely different HLA antigens, and neither possessed the HLA-B8 or DW3 antigens.

\section{DISCUSSION}

The striking clinical features of the two brothers were the long-standing ptosis and ophthalmoplegia. These abnormalities were improved markedly with intravenous edrophonium hydrochloride, and this suggested a diagnosis of congenital myasthenia gravis rather than ocular myopathy, although there was a poor clinical response to oral anticholinesterase drugs. The Kearns-Sayre type of oculosomatic myopathy and other familial progressive ophthalmoplegias were further excluded by the normal muscle biopsy (Olson et al., 1972; Iannacone et al., 1974). Routine concentric needle EMG and repetitive supramaximal nerve stimulation test were both normal, but the single fibre EMG study showed both increased neuromuscular jitter and impulse blocking; these findings are typical of those found in myasthenia gravis (Ekstedt, 1964; Stålberg et al., 1974) and illustrate the usefulness of single fibre EMG studies in the diagnosis of myasthenia gravis even when the muscle studied is clinically normal, and when conventional EMG studies are unhelpful. The observation of neuromuscular blocking during single fibre EMG without a significant decremental response of the evoked motor action potential, recorded with surface electrodes, is probably due to intermittent blocking of individual endplates, with recruitment of additional action potentials during continued activity (Schwartz and Stålberg, 1975). The age of onset of the ptosis and ophthalmoplegia and the lack of progression are characteristic of congenital myasthenia (Bundey, 1972). Feeding difficulties have occasionally been reported in infants with congenital myasthenia (McLean and McKone, 1973) but these were not observed in our two cases, although the more severely affected patient, case 2, had a weak cry in infancy.
Although the ptosis was responsive to intravenous edrophonium there was no sustained response to treatment with oral pyridostigmine. This disappointing response to oral anticholinesterase therapy has been noted in previous reports of congenital myasthenia (see Bundey, 1972). Although thymectomy is well-established in the treatment of adult-onset myasthenia gravis, only a few patients with congenital myasthenia have been treated by thymectomy and the results have varied. Keynes (1954) described a man aged 42 years whose congenital myasthenia was helped by thymectomy. Of two other cases, each 4 years old, one improved and one did not (Teng and Osserman, 1956; Motoki et al., 1966). Vetters and Simpson (1974) described the thymic histology in two girls aged 2 years but did not indicate whether there was improvement after the operation. The thymic histology in all these reported operated cases, and in two cases dying suddenly in infancy (Oosterhuis, 1964; McLean and McKone, 1973) was normal, as it was in our two patients. In contrast, in myasthenia gravis beginning after the age of 2 years the thymus is usually hyper- $\stackrel{\oplus}{+} \vec{N}$ plastic (Seybold et al., 1971). Both our patients felt $\square \vec{\sim}$ stronger and were able to work longer without $\stackrel{\vec{P}}{\overrightarrow{0}} \overrightarrow{\mathrm{c}}$ fatigue after thymectomy and this correlated with the improvement observed in the single fibre EMG findings in the extensor digitorum communis (Table 2). There are no reports of the effect of steroid therapy in congenital myasthenia gravis.

The role of disease susceptibility antigens associated with the HLA region in myasthenia gravis is not yet clear. HLA-B8 is present in 50 to $60 \%$ of adult-onset myasthenia, and in only 20 to $30 \%$ of the normal population (Behan et al., 1973; Fritze et al., 1974). HLA-DW3 is strongly associated with HLA-B8 (Haakinen et al., 1975), and HLA-A1 occurs with increased frequency in myasthenic patients because it is in linkage disequilibrium with HLA-B8 (Pirskanen, 1976). The association of other HLA antigens with myasthenia has little significance (Fritze et al., 1974). The nature of the susceptibility

TABLE 3

HLA GENOTYPE OF FAMILY

\begin{tabular}{lll}
\hline $\begin{array}{l}\text { Family } \\
\text { member }\end{array}$ & $\begin{array}{c}\text { Paternal HLA } \\
\text { haplotypes }\end{array}$ & $\begin{array}{c}\text { Maternal HLA } \\
\text { haplotypes }\end{array}$ \\
\hline $\begin{array}{l}\text { Case 1 } \\
\text { Case 2 }\end{array}$ & A1-B17 & A2-B12 \\
Sister & A3-B7 3 & A1-BW22-CW3 \\
Mother & A1-B17 & Absent \\
Father & Absent & Absent -BW22-CW3 \\
(calculated) & Absent & Absent \\
\hline
\end{tabular}


to myasthenia gravis conferred by possession of the HLA-B8-DW3 haplotype is obscure. In adult-onset familial myasthenia, for example, the disease has been observed in siblings possessing different HLA haplotypes, with or without HLA-B8 (Pirskanen, 1976), and in twins or HLA-identical siblings myasthenia gravis may develop in only one partner (Dick et al., 1974).

There is only one report of HLA typing in a family in which two siblings had congenital myasthenia (Dick et al., 1974). In this family two affected sisters inherited different haplotypes from their father, and HLA-A1-B8 from their mother. However, since their mother was homozygous for HLA-A1-B8 and no HLA-DW typing was established it was not possible to decide whether these two sisters inherited the same chromosome from her. The two brothers we have described, however, inherited different HLA haplotypes from each parent, although neither was HLA-B8, and on this evidence these patients do not share a common HLA region on chromosome 6 . The genes involved in conferring susceptibility to myasthenia in these two brothers are not associated, therefore, with the HLA system in general, or the HLA-A1, HLA-B8 or HLA-DW3 antigens in particular. These two cases differ in this respect from the two sisters with congenital myasthenia reported by Dick et al. (1974).

The problem of the nature of disease susceptibility genes, and their relation to HLA haplotypes in diseases such as myasthenia gravis, in which there is a statistical association between a particular HLA antigen and the disease, is well illustrated by familial cases in whom the association is absent. However, in the example of congenital myasthenia gravis, the clinical differences between this disease and adultonset myasthenia, and the differing HLA findings, support their separate classification and, further, suggest that their pathogenesis may not be identical.

\section{REFERENCES}

Behan, P. O., Simpson, J. A., and Dick, H. (1973). Immune response genes in myasthenia gravis. Lancet, 2, 1033.

Bradley, B. A., Edwards, J. M., Dunn, D. C., and Calne, R. Y. (1972). Quantitation of mixed lymphocyte reaction by gene dosage phenomenon. Nature, 240, 54-56.

Bundey, S. (1972). A genetic study of infantile and juvenile myasthenia gravis. Journal of Neurology, Neurosurgery, and Psychiatry, 35, 41-51.

Dick, H. M., Behan, P. O., Simpson, J. A., and Durward, W. F. (1974). The inheritance of HLA antigens in myasthenia gravis. Journal of Immunogenetics, 1, $401-412$.
Dubowitz, V., and Brooke, M. H. (1973). Muscle Biopsy: a Modern Approach. Saunders: London.

Ekstedt, J. (1964). Human single muscle fiber action potentials. Acta Physiologica Scandinavica, 61, suppl. 226, 1-96.

Festenstein, H., Adams, E., Burke, J., Oliver, R. T. D., Sachs, J. A., and Wolf, E. (1972). The distribution of HLA antigens in expatriates from East Bengal living in London. In Histocompatibility Testing, pp. 175-178. Munksgaard: Copenhagen.

Fritze, D., Herrman, C., Naeim, F., Smith, G., and Walford, R. (1974). HLA antigens in myasthenia gravis. Lancet, 1, 240-242.

Haakinen, A., Pirskanen, R., and Tiilikainen, A. (1975). LA antigens associated with HLA 8 and myasthenia gravis. Tissue Antigen, 6, 175-182.

Iannacone, S. T., Griggs, R. C., Markesbery, W. R., and Joynt, R. J. (1974). Familial progressive external ophthalmoplegia and ragged-red fibres. Neurology (Minneap.), 24, 1033-1038.

Joint Report (1975). Histocompatibility Testing, pp. 414 458. Munksgaard: Copenhagen.

Keynes, G. (1954). Surgery of the thymus gland; second (and third) thoughts. Lancet, 1, 1197-1202.

McLean, W. T. and McKone, R. C. (1973). Congenital myasthenia gravis in twins. Archives of Neurology (Chic.), 29, 223-226.

Motoki, R., Havada, M., Chiba, A., and Houde, K. (1966). A case of myasthenia gravis of identical twin brothers. International Surgery, 45, 674-677.

Olson, W., Engel, W. K., Walsh, G. O., and Einaugler, R. (1972). Oculocraniosomatic neuromuscular disease with 'ragged red' fibres. Archives of Neurology (Chic.), 26, 193-211.

Oosterhuis, H. J. (1964). Studies in myasthenia gravis. Part 1. A clinical study in 180 patients. Journal of the Neurological Sciences, 1, 512-546.

Pirskanen, R. (1976). Genetic associations between myasthenia gravis and HLA system. Journal of Neurology, Neurosurgery, and Psychiatry, 39, 23-33.

Robinette, M., Sachs, J. A., Burke, J. M., and Festenstein, H. (1975). Lymphocyte activating determinants in English caucasoids. In Histocompatibility Testing, pp. 482-489. Munksgaard: Copenhagen.

Schwartz, M.S., and Stålberg, E. (1975). Single fibre EMG studies in myasthenia gravis with repetitive nerve stimulation. Journal of Neurology, Neurosurgery, and Psychiatry, 38, 678-682.

Seybold, M. E., Howard, F. M., Duane, D., Payne, W. S., and Harrison, E. G. (1971). Thymectomy in juvenile myasthenia gravis. Archives of Neurology (Chic.), 25, 385-392.

Stålberg, E., Ekstedt, J., and Broman, A. (1974). Neuromuscular transmission in myasthenia gravis studied with single fibre electromyography. Journal of Neurology, Neurosurgery, and Psychiatry, 37, 540-547. 
Teng, P., and Osserman, K. E. (1956). Studies in myasthenia gravis. Neonatal and juvenile types. Journal of Mount Sinai Hospital, 23, 711-727.

Vetters, J. M., and Simpson, J. A. (1974). Comparison of thymic histology with response to myasthenia gravis.
Journal of Neurology, Neurosurgery, and Psychiatry, 37, 1139-1145.

Warrier, C. B. C., and Pillai, T. D. G. (1967). Familial myasthenia gravis. British Medical Journal, 3, 839-840. 